\title{
Effects of a Salicylic Acid Analog on Aphis gossypii and Its Predator Chrysoperla carnea on Melon Plants
}

\author{
Ana Moreno-Delafuente ${ }^{1}\left(\mathbb{D}\right.$, Elisa Garzo ${ }^{2}$, Alberto Fereres ${ }^{2,3}{ }^{(\mathbb{C}}$, Elisa Viñuela ${ }^{1,3}$ and \\ Pilar Medina 1,3,*iD \\ 1 Escuela Técnica Superior de Ingeniería Agronómica, Alimentaria y de Biosistemas, \\ Universidad Politécnica de Madrid (ETSIAAB-UPM), Avd. Puerta de Hierro 2-4, 28040 Madrid, Spain; \\ ana.moreno@upm.es (A.M.-D.); elisa.vinuela@upm.es (E.V.) \\ 2 Instituto de Ciencias Agrarias, Consejo Superior de Investigaciones Científicas (ICA-CSIC), \\ C/Serrano 115 dpdo., 28006 Madrid, Spain; elisa.garzo@ica.csic.es (E.G.); a.fereres@csic.es (A.F.) \\ 3 Associate Unit IVAS (CSIC-UPM): Control of Insect Vectors of Viruses in Horticultural Sustainable Systems, \\ 28006 Madrid, Spain \\ * Correspondence: pilar.medina@upm.es; Tel.: +34-91-067-10-64
}

Received: 12 September 2020; Accepted: 19 November 2020; Published: 21 November 2020

\begin{abstract}
The salicylic acid analog BTH (benzo-(1,2,3)-thiadiazole-7-carbothioic-acid S-methyl ester) induces systemic acquired resistance by promoting plant resistance against numerous plant pathogens and some insect pests. The objective of the research was to evaluate the activation of plant defenses with BTH on melon (Cucumis melo L., Cucurbitaceae) and its effects on the herbivore Aphis gossypii Glover, 1877 (Hemiptera: Aphididae) and on the aphid predator Chrysoperla carnea (Stephens, 1836) (Neuroptera: Chrysopidae). Under laboratory conditions, plants were sprayed with BTH (50 g/ha) zero (B0), four (B4), and seven (B7) days prior exposure to insects. B0 treatment resulted in 100\% mortality of aphid nymphs and disrupted adult feeding behavior (recorded by electrical-penetration-graphs technique), by prolonging the time to reach the phloem, requiring more probes to first salivation and reducing ingestion activities. There were no effects on feeding behavior of $A$. gossypii fed on B4 plants but on its life history because fewer nymphs were born, intrinsic rate of natural growth decreased, and mortality increased. There were no effects on biological parameters of aphids reared on B7 plants. Prey consumption by C. carnea larvae when predated A. gossypii fed on BTH-treated plants was not different among treatments. Therefore, BTH enhances the suppression of $A$. gossypii in the short term, without negative effects on the predatory larva C. carnea, which makes this plant strengthener a useful tool to be considered in integrated pest management programs.
\end{abstract}

Keywords: biological control; electrical penetration graphs (EPG) technique; elicitors; feeding efficiency; integrated pest management (IPM); pest control; plant defenses; plant strengtheners

\section{Introduction}

Plants respond to herbivores and pathogens with a wide range of physical and chemical defenses [1,2]. The last can be constitutive, inducible, and even indirect through the use of nectars and volatile organic compounds (VOCs) that attract natural enemies of pests [3,4]. Chemical defenses involve complex processes with cascading reactions that use molecules, signals, and regulators with an initial short-term response at membrane level when the plant receptors detect the presence of phytophagous pests and the subsequent trigger of induced direct and indirect defenses [4]. Systemic acquired resistance (SAR) is a type of induced long-lasting defense response [5], very effective against biotrophic and hemibiotrophic pathogens and some insect herbivores [6]. The induction of SAR is signaled by the phytohormone salicylic acid (SA) and it is associated with pathogenesis-related proteins 
accumulation $[7,8]$. Elicitors are conserved molecular patterns of pathogens and pests recognized by plant transmembrane receptors that activate defense events termed pattern-trigged immunity (PTI). Besides, plant intracellular receptors identify attacker virulence molecules known as effectors inducing effector-trigged immunity (ETI). Both defense responses, PTI and ETI, are mediated by a complex hormonal crosstalk $[9,10]$. Generally, the SA signaling pathway is activated by biotrophs and some sucking insects (aphids and thrips) while necrotrophs, chewing insects, and cell-sucking acari induce jasmonic acid (JA) cascade reactions to regulate defenses [4,11].

The active ingredient benzo-(1,2,3)-thiadiazole-7-carbothioic acid S-methyl ester (BTH), also called acibenzolar-S-methyl (ASM), a SA analog, can trigger a SAR response promoting plant resistance against viruses, fungi, and bacteria [6,12-14]; even conferring resistance against aphids and other herbivorous insects [15-17]; and moreover, increasing parasitoid attraction to herbivore-damaged plants [18-21]. This plant strengthener has minimal negative effects on human health and environment, although it could have an "allocation fitness cost", as SAR activation might reduce plant growth $[5,7,22]$. Despite this negative effect, the inclusion of elicitors within integrated pest management (IPM) practices will probably allow the reduction of pesticide use and/or to enhance the biological control, for example by changing the emission of VOCs or increasing nectar production that attracts parasitoids $[1,3,16,20]$.

To our knowledge, limited information has been reported about the effect of BTH on melon (Cucumis melo L., Cucurbitaceae), an important fruit crop worldwide, with $1.05 \times 10^{6}$ ha and $2.7 \times 10^{7}$ tonnes production in 2018 [23]. It is known that BTH could induce melon defense responses against pathogens of soil-borne diseases and could also prevent postharvest fruit infection [24-26]. However, no information has been noticed about the effect of BTH on piercing-sucking pests, which could be a vector of melon pathogens, and on predators as biocontrol agents. Furthermore, it is not clear from literature how much earlier plant defenses must be activated to observe an effect of the elicitor since it seems to be dependent on the specific plant-pathogen/pest system studied, the kind of elicitor, the type of induction, and the means of activation of defenses [5,22].

Therefore, in order to better understand BTH-effects, this study was performed in a tritrophic system commonly found in melon crops. We chose the cotton-melon aphid, Aphis gossypii Glover, 1877 (Hemiptera: Aphididae), one of its principal aphid pest species, with an overall economic impact as a vector of plant viruses affecting melon and other important crops [27,28]. The natural enemy selected was the cosmopolitan and polyphagous predator Chrysoperla carnea (Stephens, 1836) (Neuroptera: Chrysopidae), which is commonly found in natural and agricultural ecosystems all over the world and is commercially available in many countries for the control of aphids and other soft-body herbivore insects in greenhouse crops $[29,30]$. The stated hypothesis was that the potential activation of plant defenses with BTH could lead to changes in the development, reproduction, and feeding behavior of A. gossypii on melon plants, and subsequently could affect the feeding efficiency (i.e., prey consumption) of the predatory larva C. carnea. The effects of this elicitor at different application periods on the tritrophic system are discussed.

\section{Materials and Methods}

\subsection{Chemical and Treatments}

Melon plants were sprayed to the point of run-off with BION ${ }^{\circledR}$ [acibenzolar-S-methyl (BTH) $50 \%$ $w / w$, WG, Syngenta Crop Protection AG, Basel, Switzerland] at $50 \mathrm{~g}$ of active ingredient/ha and $300 \mathrm{~L} / \mathrm{ha}$ $\left(0.167 \mathrm{~g} \mathrm{BION}^{\circledR} / \mathrm{L}\right.$ and $0.023 \mathrm{~L} /$ plant $)$, as recommended by the manufacturer. Aqueous fresh solution was prepared with distilled water immediately prior to the application with a hand sprayer.

Three different application times were chosen to detect the potential activation of melon plants' defenses by BTH: zero (B0), four (B4), and seven (B7) days before first aphid contact with plants. Control plants were sprayed with distilled water the day of aphid exposure. Insects were placed on melon plants as soon as BTH residues or water had dried (3-4 h later). 


\subsection{Plants and Insects: General Aspects}

Melon cv. Sancho (Syngenta Seeds B.V., Enkhuizen, The Netherlands), a hybrid melon cultivar (toad skin type) widely planted in Central Spain was used for the experiments.

The clonal A. gossypii colony was originally started from a single virginoparous apterae collected from melon in El Ejido, Spain, in 1998. Laboratory colony was reared on melon plants and renewed every fortnight inside plastic aphid-proof cages in walk-in environmental chambers $\left(23: 18{ }^{\circ} \mathrm{C}\right.$ temperature, $75 \%$ relative humidity $(\mathrm{RH})$, and 16:8 light:dark (L:D) photoperiod).

Both plants and aphids were maintained at the Crop Protection Unit, Escuela Técnica Superior de Ingeniería Agronómica, Alimentaria y de Biosistemas-Universidad Politécnica de Madrid (ETSIAAB-UPM, Madrid, Spain), and at the Insect Vectors of Plant Pathogens laboratory, Institute of Agricultural Sciences-Spanish National Research Council (ICA-CSIC), where the different experiments were performed.

Chrysoperla carnea larvae were initially purchased from Agrobio (La Mojonera, Almería, Spain) and maintained for several generations in a climatic chamber $\left(25 \pm 2{ }^{\circ} \mathrm{C}, 75 \pm 5 \% \mathrm{RH}\right.$ and 16:8 (L:D) photoperiod) at the ETSIAAB-UPM laboratory, following standard rearing procedures [31]. To obtain third larval stage L3 $(<24 \mathrm{~h})$ for the experiments, a gauze was put on top of the adult rearing plastic cage to allow mated females to lay eggs for $24 \mathrm{~h}$. Then, the gauze with the eggs was placed in a new cage with zig-zag filter paper and Ephestia kuehniella (Zeller) eggs ad libitum (as food for newly-emerged larvae). Once larvae reached L2 stage, they were individually placed with E. kuehniella eggs ad libitum to avoid cannibalism. Change in the larval stage was verified with the molt presence.

\subsection{Aphis gossypii Individual Fitness}

Melon was transplanted twice in 1:1 mixture of soil substrate (Projar S.A., Valencia, Spain) and vermiculite (No. 3, Projar S.A., Valencia, Spain), first from germination in darkness $(20$ seeds $/ 15 \mathrm{~cm}$ glass Petri dish with wet filter paper on the bottom) to $7 \times 7 \mathrm{~cm}$ cell seedling trays at seven-days-old $(\mathrm{BBCH}$ stage $=10)$ [32], and from there to the definite potting in $10.5 \mathrm{~cm}$ diameter containers at $\mathrm{BBCH}$ stage $=14$. Plants were maintained in a walk-in environmental chamber, at $23.35 \pm 0.03{ }^{\circ} \mathrm{C}$, $87.17 \pm 0.37 \% \mathrm{RH}$, and 16:8 (L:D) h photoperiod. Temperature and humidity data were recorded every hour with a data logger (Tinytag Ultra 2, Gemini Data Loggers, Chichester, UK). Once a week, plants were fertilized (multifunctional fertilizer COMPO NPK $7+5+6+$ microelements, COMPO EXPERT GmbH, Münster, Germany). Five-week-old melon plants (BBCH stage $=15)$ were used in the experiment, performed at ETSIAAB-UPM laboratory.

Aphids were reared in a controlled environmental chamber (SANYO-MLR 351, Osaka, Japan) at $23-19{ }^{\circ} \mathrm{C}, 75 \% \mathrm{RH}$, and 16:8 $\mathrm{h}(\mathrm{L}: \mathrm{D})$ photoperiod and synchronized for the experiment. Then, to guarantee same-aged aphids, adult females from the laboratory colony were placed on 5-week-old melon plants. Aphids were maintained for $24 \mathrm{~h}$ inside clip-cages ( $3 \mathrm{~cm}$ diameter) with a mesh at the top to allow ventilation, then adults were removed with a wet paintbrush and the new nymphs were left on plants to develop into adults until the bioassay.

To analyze the effect of BTH on the biological parameters of $A$. gossypii, a single adult apterae female (8-9 days old since birth) was placed on the adaxial side of the second true-leaf of 5-week-old melon plants. This day was considered the beginning of the bioassay. Aphid females were confined for $24 \mathrm{~h}$ to generate offspring in a $3 \mathrm{~cm}$ diameter clip-cage. Afterward, only one neonate nymph was left per plant, which was monitored until adulthood. Then, adult offspring were counted by removing its nymphs daily until adults complete a period equal to the pre-reproductive period (number of days from birth to the onset of its reproduction) [33,34]. Aphid survivorship, duration of each nymphal instar (presence of exuvia was indicative of molting), pre-reproductive period (d), effective fecundity (offspring produced during period equal to pre-reproductive period) $(M d)$, intrinsic rate of natural increase $(r m=0.738(\ln M d) / d)[35,36]$, mean generation time $(T d=d / 0.738)$, and mean relative growth rate $(R G R=r m / 0.86)$ [37] were calculated. Plants' position inside the environmental chamber was randomized every day to avoid any positional effect. Each replicate consisted of a single aphid and 
plant. Due to the limited space inside the environmental chamber, in the first experiment, control, and B0 treatments were compared ( $n=34$ replicates, respectively), and in a second one, control, B4 and B7 treatments ( $n=22,25$, and 25 respectively). For the B0 treatment, only aphid survival was analyzed as all nymphs died before the sixth day of monitoring.

\subsection{Aphis gossypii Feeding Behavior}

Five-week-old melon plants were used in this experiment conducted at ICA-CSIC. Melon was seeded every week to have enough plants for the trials. Seven-day-old seedlings were transplanted into 1:1 mixture of soil substrate (GoV4, Jiffy International, A.S., Stange, Norway) and vermiculite (No. 3, Asfaltex S.A., Barcelona, Spain) in $8 \times 8 \times 8 \mathrm{~cm}$ pots. Plants were placed in the growth chamber at $24: 20{ }^{\circ} \mathrm{C}$ (L:D), $60-100 \% \mathrm{RH}$, and 16:8 $\mathrm{h}$ (L:D) photoperiod. Plants were watered on alternate days with $50 \mathrm{~mL} /$ plant and fertilized with 20-20-20 N-P-K (Miller Chemical and Fertilizer Corp., Hanover, PA, USA) added to the irrigation water $(1 \mathrm{~g} / \mathrm{L})$.

Aphis gossypii colonies were reared on melon plants inside rearing cages placed in an environmental chamber at $23: 18{ }^{\circ} \mathrm{C}(\mathrm{L}: \mathrm{D}), 75 \% \mathrm{HR}$, and 16:8 h (L:D) photoperiod. Aphids were synchronized to guarantee age homogeneity at the time of the electrical penetration graph (EPG) recording.

To determine whether the application of BTH to melon plants affected A. gossypii feeding behavior, the EPG technique [38] was used to monitor in real-time the plant penetration activities of the aphid pierce-sucking mouthparts, adapting the method previously described for $A$. gossypii on cucumber (Cucumis sativus L.) [33]. Plants from the three treatments (control, B0, and B4), treated as described above, were used every time EPGs were performed. Because there were no statistical differences between aphid fitness on control plants and on B7, this treatment was not included in the feeding behavior experiment.

To facilitate wiring, apterous adult A. gossypii (11-12 days old since birth) was immobilized using a vacuum-operated plate (Eyela Aspirator A3S, Tokyo Rikakikai Co. Ltd., Tokyo, Japan). Then, an extra thin gold wire ( $2 \mathrm{~cm}$ length, $18.5 \mu \mathrm{m}$ in diameter) was attached to the aphid dorsum with a small droplet of water-based silver-conducting glue (EPG-Systems, Wageningen, The Netherlands). The opposite extreme of the gold wire was glued to a thin copper wire (2-cm length), attached to a brass pin, which was inserted into the input connector of the primary amplifier of the 4-channel Gigaohm DC-EPG device (EPG Systems, Wageningen, The Netherlands). Another copper electrode (10-cm length, 2-mm diameter) was inserted into the soil of the plant container. Aphids were placed on the abaxial side of the third of four-leaf growth-stage melon plants. Each single aphid and melon plant was used only once for EPG recordings. The probing and feeding behavior was recorded during a 6-h period, which started directly after aphids were placed on the melon leaves. The EPGs acquisition was carried out inside a Faraday cage to avoid electrical noises in an air-conditioned room $\left(24^{\circ} \mathrm{C}\right)$. Data acquisition and analysis were conducted by Stylet + v01.25 software for Windows (EPG Systems, Wageningen, The Netherlands). Finally, 20 replicates per control treatment and 24 replicates per B0 and B4 were analyzed.

The aphid associated EPG waveforms [38] analyzed in this study were: (non-probe) non-probing behavior, i.e., no stylet contact with the leaf tissue; (C) intercellular apoplastic stylet pathway where insects show a cyclic activity of mechanical stylet penetration and secretion of saliva; (E1) salivation into phloem sieve elements at the beginning of the phloem phase; and (E2) passive phloem sap uptake from the sieve elements. The term "probe" refers to any type of event during the period in which the stylets of an individual insect were in contact with plant tissue, whereas "non-probe" refers to the event with no contact between stylets and plant tissue [39]. EPG sequential and non-sequential variables related to the probing and feeding behavior, described by the different waveforms, were calculated for each EPG recording using the MS Excel workbook for automatic parameter calculation of EPG data (version 5.0) [40]. The mean \pm standard error of the 32 selected EPG sequential and non-sequential variables was calculated and organized as described in Backus et al. [41]: PPW, the proportion of individuals that produced a specific waveform type; NWEI, number of waveform events per insect, 
that is the sum of the number of events of a particular waveform divided by the total number of insects under each treatment; WDI, waveform duration per insect, calculated using the sum of the duration of each event of a particular waveform made by each individual insect that produced the waveform divided by the total number of insects under each treatment; and WDE, waveform duration (min) per event, that is the sum of the duration of the events for a particular waveform divided by the total number of events of that particular waveform under each treatment (this parameter provides information on behavior at the population level).

\subsection{Feeding Efficiency of Chrysoperla carnea}

A protocol adapted from Wanumen et al. [42] was used to analyze whether BTH had a repellent or anti-feeding action on the predator C. carnea when the prey A. gossypii fed on treated plants, as some alterations in aphid feeding behavior on BTH-treated plants had been observed previously. The L3 C. carnea was fed for three consecutive days with four instar A. gossypii nymphs (N4), previously fed over $6 \mathrm{~h}$ on BTH-treated plants, as changes in aphid feeding behavior had been already observed over this period in the prior EPG experiment. This instar was used as prey for C. carnea instead of adults, in order to know the exact number of prey ingested/day, because the latter could generate offspring. Accordingly, the aphid laboratory colony reared in ETSIAAB-UPM facilities was synchronized to have enough 5-day-old nymphs (N4) for the bioassay.

Melon seedlings were transplanted in $9 \times 9 \times 10 \mathrm{~cm}$ pots and maintained in the growth chamber at ICA-CSIC facilities as described in A. gossypii feeding behavior experiment until bioassay in ETSIAAB-UPM laboratory when plants were five weeks old. Thereafter, plants were maintained in the environmental chamber (SANYO-MLR 351) at the same environmental conditions as in ICA-CSIC. Plants from the three treatments (control, B0, and B4) were used in the bioassay. Three plots of plants per treatment, one for each day of consumption experiment, were sprayed at the same time (21 plants/treatment). The fourth true-leaf of each plant was placed in $12 \mathrm{~cm}$ cylindrical cages, with a hole with foam between the lid and the cage to protect and allow the petiole insertion. In this way, BTH could continue relocating through the plant as cutting the leaf was avoided. Filter paper was placed at the bottom of the cage to absorb moisture and prevent water condensation.

Three consecutive aphid synchronizations were performed to get enough nymphs for the experiment ( 300 adults to get $\approx 2400 \mathrm{~N} 4 /$ day, to use $\approx 1400$ ). Daily, 21 lots of $60 \mathrm{~N} 4$ aphids (the two first days) or 65 (the third day), as L3 were bigger and could need to ingest more food supply, were placed in $4 \mathrm{~cm}$ cages with ventilation ( 7 replicates $\times 3$ treatments), where they were fasting until passed to the treated plants. Aphids were transferred to the $12 \mathrm{~cm}$ cage and allowed to settle on the leaf. Nymphs were feeding on the plant for $6 \mathrm{~h}$. After this period, one L3 C. carnea $(<24 \mathrm{~h})$, that had been starved for $24 \mathrm{~h}$ to assure it had a voracious appetite, was placed on the cage and left $24 \mathrm{~h}$ to predate the nymphs. After 24 and $48 \mathrm{~h}$ later, the same procedure was repeated with new plants and aphids but transferring the same $C$. carnea larvae.

Every $24 \mathrm{~h}$, once larvae had been transferred to new experimental units, leaves with aphids (predated or not) were excised and aphids counted. The fourth day, C. carnea larvae were placed in $2.5 \mathrm{~cm}$ diameter cages and fed with untreated E. kuehniella eggs ad libitum until larvae pupated. Larvae were checked daily until pupation and adult emergence. Furthermore, $C$. carnea larvae were weighed immediately before the beginning of the bioassay $(0 \mathrm{~h})$ and $72 \mathrm{~h}$ after feeding on aphid nymphs.

The parameters evaluated were: L3 C. carnea larval development time until pupation (days), pupation length (days), daily (after 24, 48, and $72 \mathrm{~h}$ ) and total consumption of aphids (number of aphids ingested/offered), and total increase in weight after three days of contaminated prey consumption (mg). The experiment was repeated three times.

\subsection{Statistical Analysis}

Aphid survivorship data were analyzed by Kaplan-Meier survival analysis with global and pairwise multiple comparison procedures in order to compare survival curves among treatments 
(Log-Rank test, $p<0.05$ ). Censored observations were those subjects that had not died at the end of the study and those that disappeared midway in the study (aphids that escaped from clip-cages) [43].

Aphid biological parameters were studied comparing B4, B7, and control treatments for the second trial. Aphid probing and feeding behavior as well as feeding efficiency of $C$. carnea were studied comparing B4, B0, and control treatments. All data sets that followed the assumptions of normality and homoscedasticity were analyzed by one-way analysis of variance (ANOVA). When necessary, data were transformed using the SQRT $(X+1)$ to reduce heteroscedasticity. The transformed data that also followed a Gaussian distribution were analyzed by one-way ANOVA test, while the non-parametric Kruskal-Wallis test was used for variables that did not follow a normal distribution or remained heteroscedastic. Subsequently, when significant differences were found $(p<0.05)$ in the ANOVA, a post-hoc Tukey test was performed for pairwise comparisons; likewise, Kruskal-Wallis test was followed by post-hoc Dunn's pairwise comparison test with Bonferroni correction. Statistical tests were conducted using the IBM SPSS Statistics 24.0 software (package for Windows, 64-bit edition, Chicago, IL, USA) at a 0.05 significance level.

A chi-squared test (if expected values were higher than 5) or a Fisher's exact test if expected values were lower than 5 (Stat View 2, Abacus Concepts, Berkeley, CA, USA) were used to analyze the PPW among treatments.

\section{Results}

\subsection{Aphis gossypii Individual Fitness}

Survival curves of $A$. gossypii varied significantly among treatments (Log rank test, global comparisons: $\chi^{2}=112.643, \mathrm{df}=4, p \leq 0.001$ ) and that of B0 plants (BTH fresh residue) significantly differed from the rest. This treatment caused $100 \%$ mortality of $A$. gossypii nymphs in the first six days of evaluation and the individual fitness parameters could not be analyzed. The survival curve of A. gossypii reared on B4 plants (treated with BTH four days before the bioassay when the initial aphids were placed on treated plants) was significantly different from that of B7 plants. Survivorship of aphids on B4 and B7 plants was similar to that of the control of its trial (C2) (Log rank test, pairwise multiple comparison; Figure 1, Supplementary Table S1). Although no significantly different, $\mathrm{C} 2$ survival curve was lower than B7, this could be explained as there were some censored observations in C2 treatment, as some aphids disappeared from clip-cages.

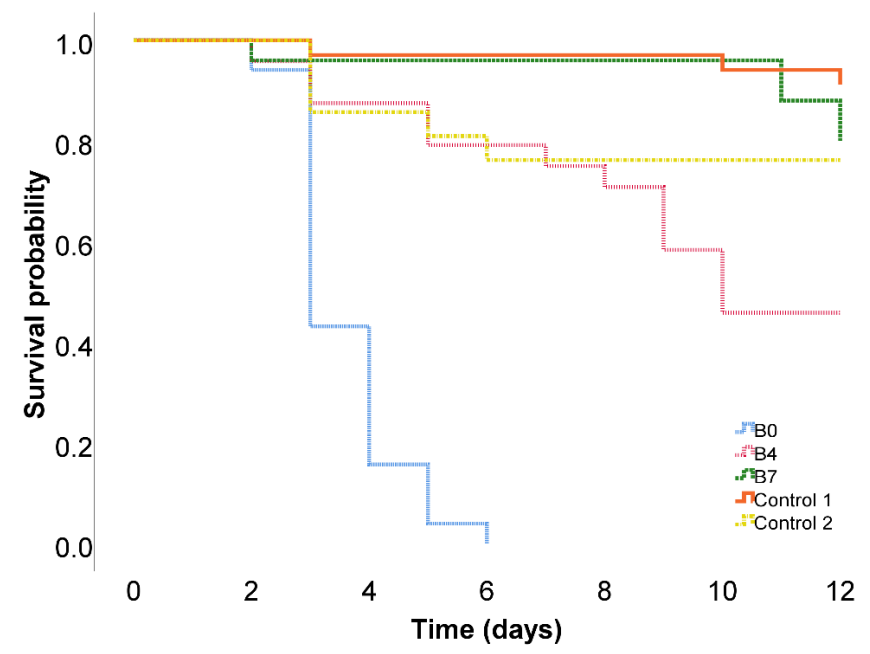

Figure 1. Survival curves of Aphis gossypii reared on melon plants sprayed with BTH (benzo-(1,2,3)-thiadiazole-7-carbothioic-acid S-methyl ester) to the point of run-off, zero (B0), four (B4), and seven (B7) days prior to aphid introduction (Log rank test, $p$-value $<0.05$ ). Control plants were sprayed with distilled water (Control 1: first trial control, Control 2: second trial control) the day of aphid introduction. 
The development time of each nymphal instar, the pre-reproductive period as well as the mean generation time of $A$. gossypii were not affected by the application of BTH in B4 and B7 plants $(p>0.05$ in all cases, Table 1). The effective fecundity $(M d)$ of aphids grown on B4 plants significantly decreased $(23.16 \%)$ compared to the control, but the effect disappeared when aphids were reared on B7 plants $(M d: \mathrm{H}=7.565, p=0.023)$ (Table 1$)$.

There was a significant reduction in the intrinsic rate of natural increase $(\mathrm{rm})$ of aphids grown on B4 plants compared to the control and to aphids grown on B7 plants. There were no differences in $\mathrm{rm}$ between aphids reared on B7 plants and the control. Because of the mean relative growth rate $(R G R)$ is a related to $r m$ by the formula $(r m=0.86 R G R)$, the same trend was observed ( $r m$ and $R G R$ : $\left.\mathrm{F}_{2,42}=8.371, p=0.001\right)$ (Table 1).

Table 1. Biological parameters of Aphis gossypii reared on melon plants treated with BTH (benzo-(1,2,3)-thiadiazole-7-carbothioic-acid S-methyl ester) to the point of run-off, four (B4), and seven (B7) days prior to aphid introduction. Control plants were sprayed with distilled water the day of aphid introduction.

\begin{tabular}{|c|c|c|c|c|}
\hline Aphid Parameter & Treatment & Mean \pm SE & Statistic Test & $p$-Value \\
\hline \multirow{3}{*}{ N1 } & Control & $1.13 \pm 0.09$ & \multirow{3}{*}{$\mathrm{H}=2.413$} & \multirow{3}{*}{0.299} \\
\hline & B4 & $1.36 \pm 0.15$ & & \\
\hline & B7 & $1.16 \pm 0.09$ & & \\
\hline \multirow{3}{*}{ N2 } & Control & $1.00 \pm 0.00$ & \multirow{3}{*}{$\mathrm{H}=3.091$} & \multirow{3}{*}{0.213} \\
\hline & B4 & $1.09 \pm 0.09$ & & \\
\hline & B7 & $1.00 \pm 0.00$ & & \\
\hline \multirow{3}{*}{ N3 } & Control & $1.07 \pm 0.07$ & \multirow{3}{*}{$\mathrm{H}=4.452$} & \multirow{3}{*}{0.108} \\
\hline & B4 & $1.18 \pm 0.12$ & & \\
\hline & B7 & $1.37 \pm 0.11$ & & \\
\hline \multirow{3}{*}{ N4 } & Control & $1.60 \pm 0.13$ & \multirow{3}{*}{$\mathrm{H}=2.914$} & \multirow{3}{*}{0.233} \\
\hline & B4 & $1.36 \pm 0.15$ & & \\
\hline & B7 & $1.32 \pm 0.11$ & & \\
\hline \multirow{3}{*}{$d$} & Control & $5.80 \pm 0.11$ & \multirow{3}{*}{$\mathrm{H}=2.316$} & \multirow{3}{*}{0.314} \\
\hline & B4 & $6.00 \pm 0.00$ & & \\
\hline & B7 & $5.84 \pm 0.09$ & & \\
\hline \multirow{3}{*}{$M d$} & Control & $59.867 \pm 1.693 \mathrm{a}$ & \multirow{3}{*}{$\mathrm{H}=7.565$} & \multirow{3}{*}{0.023 * } \\
\hline & B4 & $46.000 \pm 4.665 b$ & & \\
\hline & B7 & $52.158 \pm 2.367 \mathrm{ab}$ & & \\
\hline \multirow{3}{*}{$r m$} & Control & $0.522 \pm 0.008 \mathrm{a}$ & \multirow{3}{*}{$\mathrm{F}_{2,42}=8.371$} & \multirow{3}{*}{$0.001^{* * *}$} \\
\hline & B4 & $0.463 \pm 0.015 b$ & & \\
\hline & B7 & $0.498 \pm 0.007 \mathrm{a}$ & & \\
\hline \multirow{3}{*}{$T d$} & Control & $7.859 \pm 0.145$ & \multirow{3}{*}{$\mathrm{H}=2.316$} & \multirow{3}{*}{0.314} \\
\hline & B4 & $8.130 \pm 0.000$ & & \\
\hline & B7 & $7.916 \pm 0.116$ & & \\
\hline \multirow{3}{*}{$R G R$} & Control & $0.607 \pm 0.010 \mathrm{a}$ & \multirow{3}{*}{$\mathrm{F}_{2,42}=8.371$} & \multirow{3}{*}{$0.001^{* * *}$} \\
\hline & $\mathrm{B} 4$ & $0.538 \pm 0.017 \mathrm{~b}$ & & \\
\hline & B7 & $0.580 \pm 0.008 \mathrm{a}$ & & \\
\hline
\end{tabular}

N1-N4: first-forth instar nymphs (days); $d$ : pre-reproductive period (days); $M d$ : effective fecundity; $r m$ : intrinsic rate of natural increase; $T d$ : mean generation time (days); $R G R$ : mean relative growth rate. Different lower case letters in means within an aphid parameter indicate significant differences among treatments $\left({ }^{*} p<0.05\right.$, *** $p<0.001)$ according to ANOVA test followed by post-hoc Tukey test for normal and homoscedastic variables; or according to Kruskal-Wallis test followed by post-hoc Dunn's pairwise comparison test with Bonferroni correction, for non-normal and/or heteroscedastic variables.

\subsection{Aphis gossypii Feeding Behavior}

The effect of BTH on the feeding behavior of aphids fed on B0 and B4 plants was analyzed because mortality of aphids exposed to the first treatment was very high and fecundity and growth rates were 
affected on B4 plants. However, as there were no differences in the biological parameters of A. gossypii reared on B7 plants compared to the control, this treatment was not considered.

In general, for the majority of variables studied, feeding behavior of aphids exposed to control plants (C) did not differ significantly from the other two treatments (B0-B4) (Table 2). The probing activities measured by the number of waveform events per insect (NWEI) of "probe", intercellular stylet pathway " $C$ " and "short probes" ( $C<3 \mathrm{~min})$, were significantly more numerous in aphids feeding in B0 plants compared to B4 ones ( $p<0.05$ in all cases, Table 2). The duration of the "probe" waveform per insect (WDI) was significantly shorter while the duration of " $\mathrm{C}$ " was significantly longer on aphids feeding in B0 plants compared to B4 ones $(p<0.05$ in both cases, Table 2). No differences were observed in the duration of the "probe" event as well as in the " $\mathrm{C}$ " event (WDE) among treatments (WDE, $p>0.05$ in both cases, Table 2). The percentage of probing time spent in intercellular stylet pathway activities (" $\mathrm{C}$ ") was significantly higher in aphids feeding in B0 plants compared to those feeding in B4 ones $(p<0.05$, Figure 2$)$. There were significantly more "non-probe" events (NWEI) and its durations per aphid (WDI) and per event (WDE) were significantly longer in aphids feeding in B0 plants compared to those feeding in B4 plants ( $p<0.05$ in all cases, Table 2).

Regarding phloem-related activities, the number of phloem salivation ("E1"), ingestion ("E2"), and "E1 that was not followed by E2" ("single E1"), did not differ significantly among treatments (NWEI, $p>0.05$ in all cases, Table 2). However, the number of "sustained E2" (longer than $10 \mathrm{~min}$ ) (sE2) was significantly lower in aphids feeding in B0 plants compared with those feeding in B4 plants (NWEI, $p<0.05$, Table 2). The proportion of aphids fed on B0 plants (PPW $=14 / 24$ ) that produced "sustained E2" was significantly lower than those fed on B4 plants (PPW $=21 / 24)$ or control plants $(\mathrm{PPW}=18 / 20)\left(\mathrm{B} 0-\mathrm{B} 4: \chi^{2}: 5.169, p=0.023\right.$; B0-C: $\chi^{2}: 5.515, p=0.019$; B4-C: Fisher's Exact $\left.p>0.999\right)$ (Table 2). There was a 50\% significant reduction in the duration of ingestion ("E2") phase (WDI) in aphids feeding in B0 plants compared to B4 and control plants, and these two treatments were not significantly different (WDI, $p<0.05$, Table 2). The percentage of probing time spent in ingestion activities ("E2") was significantly lower in aphids feeding in B0 plants than in B4 or control plants and the two last treatments did not differ between them $(p<0.05$, Figure 2$)$.

No differences were observed in the duration of "E1" or "single E1" per insect among treatments (WDI, $p>0.05$, Table 2), neither in the duration per event of phloem-related activities "E1", "single E1" and "E2" (WDE, $p>0.05$, Table 2). No differences in the percentage of probing time spent in salivation ("E1") were observed among treatments ( $p>0.05$, Figure 2$)$. 
Table 2. Mean \pm standard error ( $\mathrm{min}$ ) of non-sequential electrical penetration graph (EPG) variables and their ranges in parenthesis for the feeding behavior of Aphis gossypii exposed to melon plants at 0 (fresh residue) (B0) and 4 days (B4) after sprayed BTH (benzo-(1,2,3)-thiadiazole-7-carbothioic-acid S-methyl ester), using water-sprayed plants as control, during a six-hour recording.

\begin{tabular}{|c|c|c|c|c|c|c|c|c|c|c|c|}
\hline Variables & Treatment & PPW & NWEI & Test Statistic & $p$-Value & WDI & Test Statistic & $p$-Value & WDE & Test Statistic & $p$-Value \\
\hline Non-probe & $\begin{array}{l}\text { Control } \\
\text { B0 } \\
\text { B4 }\end{array}$ & $\begin{array}{l}20 / 20 \\
24 / 24 \\
24 / 24\end{array}$ & $\begin{array}{c}16.15 \pm 1.62(5.00-32.00) \mathrm{ab} \\
22.38 \pm 2.22(3.00-41.00) \mathrm{a} \\
13.96 \pm 1.72(4.00-33.00) \mathrm{b}\end{array}$ & $\mathrm{F}_{2,65}=4.725$ & $0.012 *$ & $\begin{array}{c}26.90 \pm 3.68(6.23-63.04) \mathrm{ab} \\
43.44 \pm 5.04(2.83-98.84) \mathrm{a} \\
23.58 \pm 4.27(1.87-96.76) \mathrm{b}\end{array}$ & $\mathrm{H}=10.461$ & $0.005^{* *}$ & $\begin{array}{c}1.68 \pm 0.10(0.10-16.82) \mathrm{ab} \\
1.95 \pm 0.10(0.03-28.34) \mathrm{a} \\
1.70 \pm 0.10(0.06-13.66) \mathrm{b}\end{array}$ & $\mathrm{H}=6.876$ & $0.032 *$ \\
\hline Probe & $\begin{array}{l}\text { Control } \\
\text { B0 } \\
\text { B4 }\end{array}$ & $\begin{array}{l}20 / 20 \\
24 / 24 \\
24 / 24\end{array}$ & $\begin{array}{c}16.15 \pm 1.62(5.00-32.00) \mathrm{ab} \\
22.29 \pm 2.21(3.00-40.00) \mathrm{a} \\
13.96 \pm 1.72(4.00-33.00) \mathrm{b}\end{array}$ & $\mathrm{H}=8.526$ & $0.014 *$ & $\begin{array}{l}333.10 \pm 3.68(296.96-353.77) \mathrm{ab} \\
316.56 \pm 5.04(261.16-357.17) \mathrm{b} \\
337.89 \pm 4.65(263.24-381.28) \mathrm{a}\end{array}$ & $\mathrm{H}=10.918$ & $0.004 * *$ & $\begin{array}{l}20.63 \pm 3.03(0.19-331.00) \\
14.20 \pm 1.72(0.17-340.44) \\
24.14 \pm 3.44(0.17-351.50)\end{array}$ & $\mathrm{H}=5.883$ & 0.053 \\
\hline C & $\begin{array}{l}\text { Control } \\
\text { B0 } \\
\text { B4 }\end{array}$ & $\begin{array}{l}20 / 20 \\
24 / 24 \\
24 / 24\end{array}$ & $\begin{array}{c}17.55 \pm 1.81(5.00-35.00) \mathrm{ab} \\
25.13 \pm 2.65(3.00-51.00) \mathrm{a} \\
15.67 \pm 1.92(5.00-39.00) \mathrm{b}\end{array}$ & $\mathrm{H}=8.061$ & $0.018^{*}$ & $\begin{array}{c}157.68 \pm 18.36(44.61-313.89) \mathrm{ab} \\
221.99 \pm 17.94(58.63-321.45) \mathrm{a} \\
145.58 \pm 18.81(16.38-336.68) \mathrm{b}\end{array}$ & $H=9.413$ & $0.009 * *$ & $\begin{array}{c}8.98 \pm 0.65(0.19-65.52) \\
8.84 \pm 0.67(0.17-161.44) \\
9.27 \pm 0.70(0.14-99.43)\end{array}$ & $\mathrm{F}_{2,1328}=0.100$ & 0.905 \\
\hline $\begin{array}{l}\text { short probes } \\
(C<3 \mathrm{~min})\end{array}$ & $\begin{array}{l}\text { Control } \\
\text { B0 } \\
\text { B4 }\end{array}$ & $\begin{array}{l}20 / 20 \\
24 / 24 \\
24 / 24\end{array}$ & $\begin{array}{c}7.95 \pm 0.93(2.00-20.00) \mathrm{ab} \\
12.71 \pm 1.61(1.00-30.00) \mathrm{a} \\
7.17 \pm 1.12(1.00-24.00) \mathrm{b}\end{array}$ & $\mathrm{H}=7.983$ & $0.018^{*}$ & & & & & & \\
\hline E1 & $\begin{array}{l}\text { Control } \\
\text { B0 } \\
\text { B4 }\end{array}$ & $\begin{array}{l}20 / 20 \\
23 / 24 \\
23 / 24\end{array}$ & $\begin{array}{c}2.25 \pm 0.31(1.00-5.00) \\
3.17 \pm 0.90(0.00-17.00) \\
2.29 \pm 0.38(0.00-8.00)\end{array}$ & $H=0.105$ & 0.949 & $\begin{array}{c}1.38 \pm 0.32(0.42-5.67) \\
3.45 \pm 1.71(0.00-41.60) \\
5.06 \pm 1.58(0.00-28.16)\end{array}$ & $\mathrm{H}=2.205$ & 0.332 & $\begin{array}{c}0.61 \pm 0.13(0.11-5.00) \\
1.09 \pm 0.38(0.08-27.82) \\
2.21 \pm 0.73(0.06-28.16)\end{array}$ & $\mathrm{H}=3.535$ & 0.171 \\
\hline single E1 & $\begin{array}{l}\text { Control } \\
\text { B0 } \\
\text { B4 }\end{array}$ & $\begin{array}{l}4 / 20 \\
8 / 24 \\
3 / 24\end{array}$ & $\begin{array}{c}0.25 \pm 0.12(0.00-2.00) \\
1.46 \pm 0.78(0.00-15.00) \\
0.13 \pm 0.07(0.00-1.00)\end{array}$ & $H=3.542$ & 0.170 & $\begin{array}{c}0.33 \pm 0.23(0.00-4.51) \\
2.77 \pm 1.70(0.00-40.75) \\
0.15 \pm 0.08(0.00-1.38)\end{array}$ & $\mathrm{H}=3.753$ & 0.153 & & & \\
\hline E2 & $\begin{array}{l}\text { Control } \\
\text { B0 } \\
\text { B4 }\end{array}$ & $\begin{array}{l}20 / 20 \\
20 / 24 \\
23 / 24\end{array}$ & $\begin{array}{l}1.95 \pm 0.29(1.00-5.00) \\
1.71 \pm 0.30(0.00-5.00) \\
2.13 \pm 0.34(0.00-7.00)\end{array}$ & $\mathrm{H}=1.390$ & 0.499 & $\begin{array}{c}170.65 \pm 22.28(5.90-308.33) \mathrm{a} \\
88.31 \pm 20.79(0.00-282.87) \mathrm{b} \\
174.76 \pm 23.17(0.00-334.86) \mathrm{a}\end{array}$ & $\mathrm{H}=10.081$ & $0.006^{* *}$ & $\begin{array}{l}87.51 \pm 17.72(0.14-308.33) \\
51.69 \pm 13.60(0.24-278.36) \\
82.24 \pm 15.70(0.15-318.71)\end{array}$ & $\mathrm{H}=2.860$ & 0.239 \\
\hline sE2 & $\begin{array}{l}\text { Control } \\
\text { B0 } \\
\text { B4 }\end{array}$ & $\begin{array}{l}18 / 20 \\
14 / 24 \\
21 / 24\end{array}$ & $\begin{array}{l}0.95 \pm 0.09(0.00-2.00) \mathrm{ab} \\
0.63 \pm 0.12(0.00-2.00) \mathrm{b} \\
1.04 \pm 0.11(0.00-2.00) \mathrm{a}\end{array}$ & $\mathrm{H}=7.930$ & $0.019^{*}$ & & & & $\begin{array}{l}177.81 \pm 21.84(14.07-308.33) \\
139.13 \pm 24.16(19.54-278.36) \\
165.62 \pm 21.90(10.56-318.71)\end{array}$ & $\mathrm{H}=1.050$ & 0.592 \\
\hline
\end{tabular}

PPW, proportion of individuals that produced the waveform type; NWEI, number of waveform events per insect; WDI, waveform duration (min) per insect; WDE, waveform duration ( $\mathrm{min})$ per event. Waveforms: C, intercellular stylet pathway; E shows phloem-related activities, E1: correlates with salivation into phloem elements; single E1: E1 not followed by E2; E2: regards as phloem ingestion; sE2: sustained E2 $(>10 \mathrm{~min})$. Different lower case letters within variables indicate significant differences among treatments $\left(^{*} p<0.05\right.$, $\left.{ }^{* *} p<0.01\right)$ according to ANOVA test followed by post-hoc Tukey test for normal and homoscedastic variables, transformed by SQRT $(X+1)$ when needed; or to Kruskal-Wallis test followed by post-hoc Dunn's pairwise comparison test with Bonferroni correction, for non-normal and/or heteroscedastic variables. 


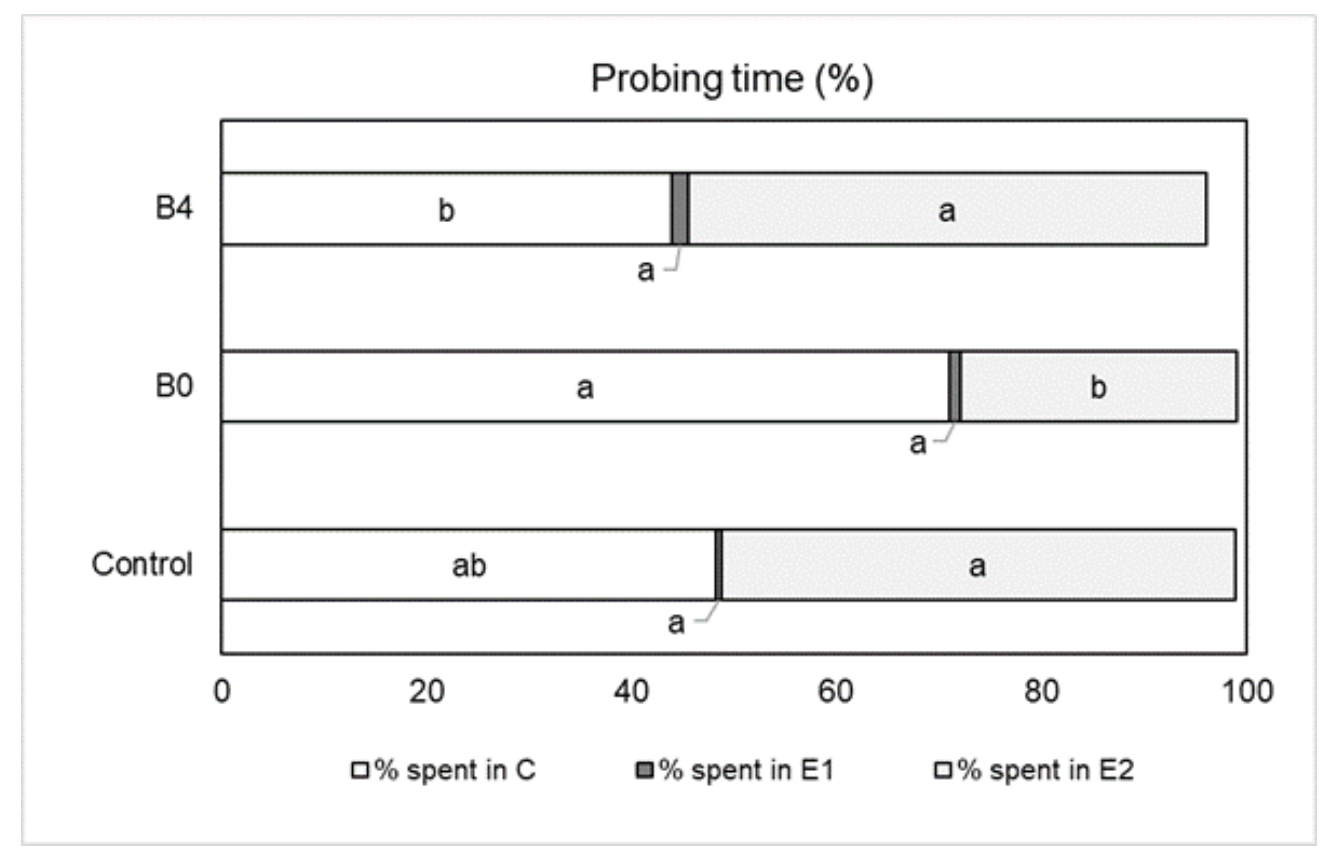

Figure 2. Percentage of probing time spent in a specific waveform when Aphis gossypii was fed on melon plants sprayed with BTH (benzo-(1,2,3)-thiadiazole-7-carbothioic-acid S-methyl ester) to the point of run-off, zero (B0) and four (B4) days prior to aphid first contact, using water-sprayed plants as control. Six-hour electrical penetration graph (EPG) recording. Waveforms: C, intercellular stylet pathway; E shows phloem-related activities: E1, correlates with salivation into phloem sieve elements; E2, regards as phloem ingestion [44]. Statistical comparisons among treatments for each parameter were made by non-parametric Kruskal-Wallis test. Means within variables followed by different lower-case letters are significantly different $(p$-value $<0.05)$.

Sequential EPG variables that describe the sequence of events related to each other during the six hours of recording are shown in Table 3. Time spent from first probe to first $\mathrm{E}$, time from first probe to first E2, time from first probe to first E2 and number of probes to the first E1 were significantly higher in aphids feeding in B0 plants than in the other two treatments, not observing differences in these variables between aphids feeding on B4 and control plants $(p<0.05$ in all cases, Table 3). Total duration of non-probe before the first $\mathrm{E}$ was significantly longer in aphids feeding in B0 plants than in B4 plants, while aphids exposed to control plants did not significantly differ from the other two treatments $(p<0.05$, Table 3$)$. Time to first probe from start of EPG, time from the beginning of that probe to first $\mathrm{E}$, time from the beginning of that probe to first $\mathrm{E} 2$ and time from the beginning of that probe to first sE2 were not significantly different among treatments ( $p>0.05$ in all cases, Table 3$)$. 
Table 3. Mean \pm standard error ( $\mathrm{min}$ ) of sequential electrical penetration graph (EPG) variables and their ranges in parenthesis for the feeding behavior of Aphis gossypii exposed to melon plants at 0 (fresh residue) (B0) and 4 days (B4) after sprayed BTH (benzo-(1,2,3)-thiadiazole-7-carbothioic-acid S-methyl ester), using water-sprayed plants as control, during a six-hour recording.

\begin{tabular}{|c|c|c|c|c|c|c|}
\hline & Sequential EPG Variables & Treatment & PPW & Mean \pm SE (Range) & Test Statistic & $p$-Value \\
\hline \multirow{24}{*}{ WDI } & \multirow{3}{*}{ Time to 1st probe from start of EPG } & Control & $20 / 20$ & $2.19 \pm 0.86(0.00-16.82)$ & \multirow{3}{*}{$\mathrm{H}=0.821$} & \multirow{3}{*}{0.663} \\
\hline & & B0 & $24 / 24$ & $1.59 \pm 0.61(0.00-14.32)$ & & \\
\hline & & B4 & $24 / 24$ & $0.85 \pm 0.20(0.00-3.44)$ & & \\
\hline & \multirow{3}{*}{ Time from 1st probe to 1st E } & Control & $20 / 20$ & $110.98 \pm 16.14(20.53-343.71) b$ & \multirow{3}{*}{$\mathrm{H}=9.586$} & \multirow{3}{*}{$0.008^{* *}$} \\
\hline & & B0 & $23 / 24$ & $190.26 \pm 19.76(43.85-345.68) \mathrm{a}$ & & \\
\hline & & B4 & $23 / 24$ & $119.60 \pm 17.58(18.99-359.94) b$ & & \\
\hline & \multirow{3}{*}{$\begin{array}{l}\text { Time from the beginning of that probe to } \\
\text { 1st E }\end{array}$} & Control & $20 / 20$ & $33.75 \pm 3.90(13.59-65.52)$ & \multirow{3}{*}{$\mathrm{H}=1.267$} & \multirow{3}{*}{0.531} \\
\hline & & B0 & $23 / 24$ & $46.03 \pm 7.91(8.98-161.44)$ & & \\
\hline & & B4 & $23 / 24$ & $38.89 \pm 8.52(10.21-206.26)$ & & \\
\hline & \multirow{3}{*}{ Time from 1st probe to 1st sE2 (>10 min) } & Control & $18 / 20$ & $172.16 \pm 20.36(51.45-358.11) b$ & \multirow{3}{*}{$\mathrm{H}=8.426$} & \multirow{3}{*}{$0.015^{*}$} \\
\hline & & B0 & $14 / 24$ & $257.93 \pm 22.03(73.44-360.00) \mathrm{a}$ & & \\
\hline & & B4 & $21 / 24$ & $170.96 \pm 22.74(19.72-359.94) b$ & & \\
\hline & \multirow{3}{*}{$\begin{array}{l}\text { Time from the beginning of that probe to } \\
\text { 1st sE2 (>10 min) }\end{array}$} & Control & $18 / 20$ & $32.41 \pm 3.51(12.87-64.21)$ & \multirow{3}{*}{$\mathrm{H}=3.630$} & \multirow{3}{*}{0.163} \\
\hline & & B0 & $14 / 24$ & $58.39 \pm 11.39(14.62-162.19)$ & & \\
\hline & & B4 & $21 / 24$ & $47.50 \pm 9.47(11.31-206.95)$ & & \\
\hline & \multirow{3}{*}{ Time from 1st probe to 1st E2 } & Control & $20 / 20$ & $125.03 \pm 17.68(20.73-344.86) b$ & \multirow{3}{*}{$\mathrm{F}_{2,65}=7.157$} & \multirow{3}{*}{$0.002^{* *}$} \\
\hline & & B0 & $20 / 24$ & $214.66 \pm 21.48(57.96-360.00) \mathrm{a}$ & & \\
\hline & & B4 & $23 / 24$ & $123.28 \pm 17.75(19.72-359.94) b$ & & \\
\hline & \multirow{3}{*}{$\begin{array}{l}\text { Time from the beginning of that probe to } \\
1 \text { st E2 }\end{array}$} & Control & $20 / 20$ & $33.97 \pm 3.93(14.08-66.68)$ & \multirow{3}{*}{$\mathrm{H}=0.728$} & \multirow{3}{*}{0.695} \\
\hline & & B0 & $20 / 24$ & $46.83 \pm 8.78(14.35-162.19)$ & & \\
\hline & & B4 & $23 / 24$ & $42.73 \pm 8.43(10.42-206.95)$ & & \\
\hline & \multirow{3}{*}{$\begin{array}{l}\text { Total duration of non-probe before the } \\
\text { 1st E }\end{array}$} & Control & $20 / 20$ & $18.19 \pm 3.06(0.20-55.34) \mathrm{ab}$ & \multirow{3}{*}{$\mathrm{H}=8.425$} & \multirow{3}{*}{$0.015^{*}$} \\
\hline & & B0 & $23 / 24$ & $30.89 \pm 4.12(2.83-83.58) \mathrm{a}$ & & \\
\hline & & B4 & $23 / 24$ & $16.54 \pm 2.47(1.51-48.80) \mathrm{b}$ & & \\
\hline \multirow{3}{*}{ NWEI } & \multirow{3}{*}{ Number of probes to the 1st E1 } & Control & $20 / 20$ & $10.95 \pm 1.23(1.00-22.00) \mathrm{b}$ & \multirow{3}{*}{$\mathrm{F}_{2,65}=4.88$} & \multirow{3}{*}{$0.011 *$} \\
\hline & & B0 & $23 / 24$ & $16.88 \pm 1.73(3.00-32.00) \mathrm{a}$ & & \\
\hline & & B4 & $23 / 24$ & $10.79 \pm 1.25(3.00-22.00) b$ & & \\
\hline
\end{tabular}

PPW, proportion of individuals that produced the waveform type; WDI, waveform duration (min) per insect; NWEI, number of waveform events per insect. Waveforms: E shows phloem-related activities: E1, correlates with salivation into phloem elements; E2, regards as phloem ingestion; sE2: sustained E2 ( $>10$ min). Different lower case letters within variables indicate significant differences among treatments $(* p<0.05, * *<0.01)$ according to ANOVA test followed by post-hoc Tukey test for normal and homoscedastic variables, transformed by SQRT $(X+1)$ when needed; or to Kruskal-Wallis test followed by post-hoc Dunn's pairwise comparison test with Bonferroni correction, for non-normal and/or heteroscedastic variables. 


\subsection{Feeding Efficiency of Chrysoperla carnea}

All C. carnea biology- and feeding-related parameters analyzed were similar among treatments $(p>0.05$ in all cases, Table 4$)$.

Table 4. Chrysoperla carnea biology and consumption parameters when third instar larvae (L3) predated forth instar nymphs of Aphis gossypii fed on melon plants treated with BTH (benzo-(1,2,3)-thiadiazole-7-carbothioic-acid S-methyl ester) the day of aphid introduction (B0) or 4 days before (B4), using water-sprayed plants as control.

\begin{tabular}{|c|c|c|c|c|c|}
\hline Chrysoperla carne & Parameter & Treatment & Mean \pm SE & Test Statistic & $p$-Value ${ }^{\text {a }}$ \\
\hline \multirow{6}{*}{ Development time (d) } & \multirow{3}{*}{ L3 } & Control & $6.53 \pm 0.46$ & \multirow{3}{*}{$\mathrm{H}=0.040$} & \multirow{3}{*}{0.980} \\
\hline & & B0 & $6.88 \pm 0.76$ & & \\
\hline & & B4 & $6.70 \pm 0.50$ & & \\
\hline & \multirow{3}{*}{ Pupae } & Control & $10.83 \pm 0.17$ & \multirow{3}{*}{$\mathrm{H}=3.123$} & \multirow{3}{*}{0.210} \\
\hline & & B0 & $10.41 \pm 0.15$ & & \\
\hline & & B4 & $10.65 \pm 0.11$ & & \\
\hline \multirow{12}{*}{ Consumption $(\%)^{b}$} & \multirow{3}{*}{$24 \mathrm{~h}$} & Control & $42.51 \pm 4.61$ & \multirow{3}{*}{$F_{2,55}=0.159$} & \multirow{3}{*}{0.854} \\
\hline & & B0 & $43.88 \pm 4.64$ & & \\
\hline & & B4 & $40.49 \pm 3.64$ & & \\
\hline & \multirow{3}{*}{$48 \mathrm{~h}$} & Control & $46.42 \pm 5.05$ & \multirow{3}{*}{$\mathrm{F}_{2,55}=1.222$} & \multirow{3}{*}{0.303} \\
\hline & & B0 & $53.61 \pm 5.26$ & & \\
\hline & & B4 & $42.75 \pm 4.71$ & & \\
\hline & \multirow{3}{*}{$72 \mathrm{~h}$} & Control & $39.37 \pm 3.63$ & \multirow{3}{*}{$\mathrm{H}=1.038$} & \multirow{3}{*}{0.595} \\
\hline & & B0 & $46.29 \pm 5.02$ & & \\
\hline & & B4 & $42.20 \pm 6.40$ & & \\
\hline & \multirow{3}{*}{ Total } & control & $42.73 \pm 3.29$ & \multirow{3}{*}{$\mathrm{F}_{2,53}=0.562$} & \multirow{3}{*}{0.573} \\
\hline & & B0 & $47.13 \pm 4.07$ & & \\
\hline & & B4 & $41.53 \pm 4.28$ & & \\
\hline \multirow{9}{*}{ Weight $(\mathrm{mg})^{\mathrm{c}}$} & \multirow{3}{*}{$0 \mathrm{~h}$} & Control & $3.72 \pm 0.29$ & \multirow{3}{*}{$\mathrm{F}_{2,30}=0.364$} & \multirow{3}{*}{0.698} \\
\hline & & B0 & $3.83 \pm 0.35$ & & \\
\hline & & B4 & $4.07 \pm 0.21$ & & \\
\hline & \multirow{3}{*}{$72 \mathrm{~h}$} & Control & $11.65 \pm 0.48$ & \multirow{3}{*}{$\mathrm{F}_{2,47}=0.210$} & \multirow{3}{*}{0.811} \\
\hline & & B0 & $11.99 \pm 0.50$ & & \\
\hline & & B4 & $12.16 \pm 0.69$ & & \\
\hline & \multirow{3}{*}{ Total increase $^{\mathrm{d}}$} & Control & $7.17 \pm 0.29$ & \multirow{3}{*}{$\mathrm{F}_{2,30}=3.049$} & \multirow{3}{*}{0.062} \\
\hline & & B0 & $8.10 \pm 0.51$ & & \\
\hline & & B4 & $8.91 \pm 0.69$ & & \\
\hline
\end{tabular}

${ }^{a}$ All data sets among each parameter were not significantly different (ANOVA, Kruskal-Wallis; $(p$-value $>0.05)$ ). b Number of Aphis gossypii nymphs, previously fed over $6 \mathrm{~h}$ on BTH-treated plants, consumed by L3 C. carnea (ingested/offered, \%) counted after 24,48 , and $72 \mathrm{~h}$. ${ }^{\mathrm{c}} \mathrm{L} 3 \mathrm{C}$. carnea were weighed immediately before the beginning of the bioassay $(0 \mathrm{~h})$ and $72 \mathrm{~h}$ after being fed with aphid nymphs (contaminated prey). ${ }^{\mathrm{d}}$ Total increase in weight after three days of contaminated prey consumption.

\section{Discussion}

Aphis gossypii has evolved resistance to the principal families of synthetic insecticides [27,45]. Owing to the fact that the application of pesticides must be reduced to achieve sustainable agriculture, the use of elicitors as plant strengtheners that could induce herbivore resistance at the same time that enhance the biological control of these pests could be an interesting strategy to be included in IPM. The BTH promotes pathogen resistance in a wide range of crops $[6,14]$, but just a few studies have explored the susceptibility of herbivore insects and mites to this elicitor [15-17,46]. It is known that BTH improves indirectly the biological control since it can increase the attractiveness of herbivore-damaged plants to parasitic wasps due to qualitative and quantitative changes in the induced volatiles emissions [19-21], but information on BTH-effect on predators is insufficient. 
There is great heterogeneity in scientific literature about how and when is necessary to apply BTH to induce plant resistance, and the time and mode of application chosen influence plants and herbivorous insects differently. BTH might be applied soaking seeds [47], spraying leaves or the whole plant [20], or as a soil drench [21]. Some researchers apply the product in young plants (1-2 weeks old) while others in older plants and just a few hours/days before the starting of the bioassays $[16,18,46,48]$. In this study, the pest was exposed to three different application periods of BTH to discern if the effect on insects' performance was due to an induction of defenses or due to a direct toxicity of the product.

A reduction in foliar thickness that finally generated necrotic lesions on BTH-sprayed leaves was observed in this experiment in agreement with phytotoxic effects detected in different plant species after application of elicitors [16,49]. Even if SA analogs are less phytotoxic than the application of SA [6,7], BTH may cause an allocation fitness cost [5]. This compound sprayed on seedlings of melon var. Orange Flesh caused an inhibition in growth from 6 days after treatment onwards and this could be related to the peroxidase activity increase. This defense-related enzyme is associated with the lignification of the plant cell wall that could increase resistance to pathogen attack, therefore, even if BTH could reduce melon growth, it finally induces its plant defenses [24]. Further biochemical research could elucidate if the BTH-effects observed in our trophic system may be related to the possible phytotoxicity.

In the present work, the EPG technique reveals that there was not a contact effect of BTH on the initial probing behavior (time from the start of the EPG recording until the first probe) of A. gossypii exposed to the different BTH-treated plants compared to the control plants. This EPG variable is associated with pre-phloem resistant factors present in epidermis or mesophyll that reduce attractiveness of the plant to the insect [50] and is used to evaluate the deterrent effect or delays in aphid probing on insecticide-treated plants [51]. In our case, BTH neither inhibited nor delayed A. gossypii initial probe on treated plants.

In agreement with Cooper et al. [17], who reported that BTH could reduce the population growth of Macrosiphum euphorbiae Thomas, 1878 on a susceptible tomato cultivar and enhance the aphid resistance in a resistant cultivar, the present research showed that fresh residues of BTH (B0 plants) prevented the population growth of $A$. gossypii in melon cv. Sancho because nymphs did not develop to maturity. The B0 plants modified probing and feeding behavior of $A$. gossypii adults thus, aphids spent more time in non-probe activities and although they could reach the phloem, they took longer to contact the sieve elements, needed more probes to salivate for the first time and finally spent less time in ingestion activities (i.e., passive phloem sap uptake). Therefore, B0 plants could have activated their defense mechanisms at phloem level in a short term, as A. gossypii cannot initiate ingestion from the phloem as when fed on control plants or B4 plants [52]. Using the same EPG recording technique, Powell and Hodge [53] observed that phloem sap ingestion was also reduced when Acyrthosiphon pisum Harris, 1776 fed on tic bean (Vicia faba var. minor L.) treated with the elicitor $\beta$-aminobutyric acid (BABA), but only when there has been a previous aphid infestation on the plants. In our study, the reduction in A. gossypii individual fitness in addition to the impairing in its feeding behavior on $\mathrm{B} 0$ plants could be more related to a direct toxic effect of fresh residue of BTH or to the increase in levels of pathogenesis-related proteins gene expression (immediate-early gene induction) [11,14,54].

In B4 plants, there was no effect on A. gossypii feeding behavior compared to the control. However, there was a clear effect on aphid life history traits because fewer nymphs were born, the intrinsic rate of natural growth decreased (also, the RGR), and the mortality increased compared to those on control plants. Therefore, an antibiosis more than an antixenosis mechanism could have reduced A. gossypii population growth when fed on these plants. Despite using different methodologies, similar effects on aphid fitness were reported in other elicitor-plant-aphid systems [16,55].

BTH can induce a long-lasting resistance against some aphids $[7,20]$, but this was not the case in the present study because A. gossypii had similar performance and survival when reared on B7 plants compared to the control. Overall, the BTH effects observed could be due to an activation of the 
defense mechanism only in the short term. For reasons still unknown, BTH does not induce prolonged resistance mechanisms against $A$. gossypii. On the other hand, BTH might be toxic to these aphids.

In this study, spray application of BTH to melon plants did not affect the feeding efficiency of $C$. carnea when predated A. gossypii fed on treated plants, independently of the application day. Similar to the results exposed here, the elicitor methyl jasmonate when applied to tomato seeds did not alter the behavior of Chrysoperla externa (Hagen, 1861) although reduced the performance of its pest, the leaf miner Tuta absoluta (Meyrick, 1917) [56]. In tritrophic systems involving elicitors and parasitoids from genus Aphidius, slight effects on the wasps' emergence were observed depending on the concentration of the compound, so specific studies case by case should be performed $[49,57]$.

Alterations in aphid feeding behavior on BTH-treated plants could also change acquisition, retention, latency, and inoculation of aphid-borne plant viruses. The greater number of short superficial probes and intracellular stylet punctures increased the transmission of a non-persistent virus [33]. On the other hand, circulative virus particles are usually ingested from phloem sieve elements [58]. Therefore, stylets penetration behavior could help to determine the effect of elicitors on the transmission efficiency of plant viruses by piercing-sucking insects [59].

\section{Conclusions}

The effects of BTH applied at fresh residue could be due to a direct toxicity of the product on the aphid that undermines its fitness and feeding behavior, causing total mortality of $A$. gossypii nymphs. When the product is applied four days before A. gossypii exposure, BTH impairs aphid fitness reducing the population growth. A short-term but not long-lasting activation of plant defenses could be pointed for seven days after BTH application the product seems to have degraded regarding the effect on the aphid. The direct effect of BTH to A. gossypii in the short term, together with the lack of effect of the elicitor on $C$. carnea feeding efficiency, are indicative that this plant strengthener contributes to enhance the suppression of the phloem-feeding insect in the trophic system studied without harming the beneficial chrysopid. However, in order to consider BTH as an interesting strategy to control aphid pests within IPM for melon crops, further research should be addressed to ascertain the molecular and biochemical mechanisms behind the observed effects on melon and aphids caused by the elicitor BTH. Thus, a more efficient use of the product could be implemented.

Supplementary Materials: The following are available online at http://www.mdpi.com/2073-4395/10/11/1830/s1, Table S1: Kaplan-Meier survival analysis of Aphis gossypii reared on melon plants sprayed with BTH to the point of run-off, zero (B0), four (B4), and seven (B7) days prior to aphid introduction. Control plants were sprayed with distilled water (C1: first trial control, compared to B0; C2: second trial control, compared to B4 and B7) the day of aphid introduction.

Author Contributions: Conceptualization, all authors; methodology, all authors; validation, P.M. and E.G.; formal analysis, A.M.-D., E.G. and P.M.; investigation, A.M.-D. and E.G.; resources, A.F., E.V., and P.M.; data curation, A.M.-D., E.G. and P.M.; writing-original draft preparation, A.M.-D. and P.M.; writing — review and editing, all authors; visualization, A.M.-D.; supervision, P.M.; project administration, A.F., E.V., and P.M.; funding acquisition, A.F., E.V., and P.M. All authors have read and agreed to the published version of the manuscript.

Funding: This work was supported by Ministerio de Economía, Industria y Competitividad, Gobierno de España (Research Grants Numbers AGL2013-47603-C2, AGL2017-83498-C2-2-R) and by a PhD grant to A.M.-D. by Ministerio de Educación, Cultura y Deporte (Fellowship Number FPU2015-05173).

Acknowledgments: We are very grateful to Sergio Estébanez and Ignacio Morales for technical assistance during the laboratory trials, and to Isabel Díaz (CBGP-UPM) who reviewed an early draft of the manuscript.

Conflicts of Interest: The authors declare no conflict of interest. The funders had no role in the design of the study; in the collection, analyses, or interpretation of data; in the writing of the manuscript, or in the decision to publish the results.

\section{References}

1. War, A.R.; Paulraj, M.G.; Ahmad, T.; Buhroo, A.A.; Hussain, B.; Ignacimuthu, S.; Sharma, H.C. Mechanisms of plant defense against insect herbivores. Plant Signal. Behav. 2012, 7, 1306-1320. [CrossRef]

2. Sequeira, L. Mechanisms of Induced Resistance in Plants. Annu. Rev. Microbiol. 1983, 37, 51-79. [CrossRef] 
3. Santamaria, M.E.; Martínez, M.; Cambra, I.; Grbic, V.; Diaz, I. Understanding plant defence responses against herbivore attacks: An essential first step towards the development of sustainable resistance against pests. Transgenic Res. 2013, 22, 697-708. [CrossRef] [PubMed]

4. Santamaria, M.E.; Arnaiz, A.; Gonzalez-Melendi, P.; Martinez, M.; Diaz, I. Plant perception and short-term responses to phytophagous insects and mites. Int. J. Mol. Sci. 2018, 19, 1356. [CrossRef] [PubMed]

5. Yi, H.-S.; Yang, J.W.; Ryu, C.-M. ISR meets SAR outside: Additive action of the endophyte Bacillus pumilus INR7 and the chemical inducer, benzothiadiazole, on induced resistance against bacterial spot in field-grown pepper. Front. Plant Sci. 2013, 4, 1-11. [CrossRef] [PubMed]

6. Tripathi, D.; Raikhy, G.; Kumar, D. Chemical elicitors of systemic acquired resistance-Salicylic acid and its functional analogs. Curr. Plant Biol. 2019, 17, 48-59. [CrossRef]

7. Durrant, W.E.; Dong, X. Systemic Acquired Resistance. Annu. Rev. Phytopathol. 2004, 42, 185-209. [CrossRef]

8. Hammerschmidt, R. Systemic Acquired Resistance. Adv. Bot. Res. 2009, 51, 173-222.

9. Dodds, P.N.; Rathjen, J.P. Plant immunity: Towards an integrated view of plant-pathogen interactions. Nat. Rev. Genet. 2010, 11, 539-548. [CrossRef]

10. Tsuda, K.; Katagiri, F. Comparing signaling mechanisms engaged in pattern-triggered and effector-triggered immunity. Curr. Opin. Plant Biol. 2010, 13, 459-465. [CrossRef]

11. Pieterse, C.M.J.; Van der Does, D.; Zamioudis, C.; Leon-Reyes, A.; Van Wees, S.C.M. Hormonal Modulation of Plant Immunity. Annu. Rev. Cell Dev. Biol. 2012, 28, 489-521. [CrossRef] [PubMed]

12. Takeshita, M.; Okuda, M.; Okuda, S.; Hyodo, A.; Hamano, K.; Furuya, N.; Tsuchiya, K. Induction of Antiviral Responses by Acibenzolar-S-Methyl Against Cucurbit chlorotic yellows virus in Melon. Phytopathology 2013, 103, 960-965. [CrossRef] [PubMed]

13. Anfoka, G.H. Benzo-(1,2,3)-thiadiazole-7-carbothioic acid S-methyl ester induces systemic resistance in tomato (Lycopersicon esculentum Mill cv. Vollendung) to Cucumber mosaic virus. Crop Prot. 2000, 19, 401-405. [CrossRef]

14. Faize, L.; Faize, M. Functional analogues of salicylic acid and their use in crop protection. Agronomy 2018, 8, 5. [CrossRef]

15. Goggin, F.L. Plant-aphid interactions: Molecular and ecological perspectives. Curr. Opin. Plant Biol. 2007, 10, 399-408. [CrossRef]

16. Boughton, A.J.; Hoover, K.; Felton, G.W. Impact of chemical elicitor applications on greenhouse tomato plants and population growth of the green peach aphid, Myzus persicae. Entomol. Exp. Appl. 2006, 120, 175-188. [CrossRef]

17. Cooper, W.C.; Jia, L.; Goggin, F.L. Acquired and r-gene-mediated resistance against the potato aphid in tomato. J. Chem. Ecol. 2004, 30, 2527-2542. [CrossRef]

18. Sobhy, I.S.; Erb, M.; Lou, Y.; Turlings, T.C.J. The prospect of applying chemical elicitors and plant strengtheners to enhance the biological control of crop pests. Philos. Trans. R. Soc. B Biol. Sci. 2014, 369, 20120283. [CrossRef]

19. Sobhy, I.S.; Erb, M.; Sarhan, A.A.; El-Husseini, M.M.; Mandour, N.S.; Turlings, T.C.J. Less is more: Treatment with BTH and Laminarin Reduces herbivore-induced volatile emissions in maize but increases parasitoid attraction. J. Chem. Ecol. 2012, 38, 348-360. [CrossRef]

20. Sobhy, I.S.; Erb, M.; Turlings, T.C.J. Plant strengtheners enhance parasitoid attraction to herbivore-damaged cotton via qualitative and quantitative changes in induced volatiles. Pest Manag. Sci. 2015, 71, 686-693. [CrossRef]

21. Rostás, M.; Turlings, T.C.J. Induction of systemic acquired resistance in Zea mays also enhances the plant's attractiveness to parasitoids. Biol. Control 2008, 46, 178-186. [CrossRef]

22. Cipollini, D.; Heil, M. Costs and benefits of induced resistance to herbivores and pathogens in plants. CAB Rev. Perspect. Agric. Vet. Sci. Nutr. Nat. Resour. 2010, 5. [CrossRef]

23. FAO. FAOSTAT. Available online: http://www.fao.org/faostat/en/\#data/QC (accessed on 18 July 2020).

24. Gondim, D.M.F.; Terao, D.; Martins-Miranda, A.S.; Vasconcelos, I.M.; Oliveira, J.T.A. Benzo-thiadiazole-7-carbothioic acid S-methyl ester does not protect melon fruits against Fusarium pallidoroseum infection but induces defence responses in melon seedlings. J. Phytopathol. 2008, 156, 607-614. [CrossRef] 
25. Buzi, A.; Chilosi, G.; De Sillo, D.; Magro, P. Induction of Resistance in Melon to Didymella bryoniae and Sclerotinia sclerotiorum by Seed Treatments with Acibenzolar-S-methyl and Methyl Jasmonate but not with Salicylic Acid. J. Phytopathol. 2004, 152, 34-42. [CrossRef]

26. Li, X.; Bi, Y.; Wang, J.; Dong, B.; Li, H.; Gong, D.; Zhao, Y.; Tang, Y.; Yu, X.; Shang, Q. BTH treatment caused physiological, biochemical and proteomic changes of muskmelon (Cucumis melo L.) fruit during ripening. J. Proteom. 2015, 120, 179-193. [CrossRef] [PubMed]

27. Blackman, R.L.; Eastop, V.F. Taxonomic Issues. In Aphids as Crop Pests; Van Emden, H.F., Harrington, R., Eds.; CAB International: Oxfordshire, UK, 2017; pp. 1-36.

28. CABI. Aphis Gossypii. Available online: http://www.cabi.org/isc/datasheet/6204 (accessed on 11 August 2020).

29. Biobest Chrysopa. Available online: https://www.biobestgroup.com/es/biobest/productos/control-biologico4462/insectos-y-acaros-depredadores-4477/chrysopa-system-4784/ (accessed on 26 June 2020).

30. Koppert Chrysopa. Available online: https://www.koppert.com/chrysopa/ (accessed on 26 June 2020).

31. Vogt, H.; Bigler, F.; Brown, K.; Candolfi, M.P.; Kemmeter, F.; Kühner, C.; Moll, M.; Travis, A.; Ufer, A.; Viñuela, E.; et al. Laboratory method to test effects of plant protection products on larvae of Chrysoperla carnea (Neuroptera: Chrysopidae). In Guidelines to Evaluate Side-Effects of Plant Protection Products to Non-Target Arthropods; Candolfi, M.P., Blümel, S., Forster, R., Bakker, F.M., Grimm, C., Hassan, S.A., Heimbach, U., Mead-Briggs, M.A., Raber, B., Schmuck, R., et al., Eds.; IOBC/WPRS: Gent, Belgium, 2000; pp. 27-44.

32. Feller, V.C.; Bleiholder, H.; Buhr, L.; Hack, H.; Heß, M.; Klose, R.; Meier, U.; Stauß, R.; Boom, T.; van den Webe, E. Phanologische Entwicklungsstadien von Gemusepflanzen II. Fruchtgemuse und Hulsenfruchte (Phenological growth stages of vegetable crops II. Fruit vegetables and pulses). Nachrichtenbl. Deut. Pflanzenschutzd. 1995, 47, 217-232.

33. Carmo-Sousa, M.; Moreno, A.; Garzo, E.; Fereres, A. A non-persistently transmitted-virus induces a pull-push strategy in its aphid vector to optimize transmission and spread. Virus Res. 2014, 186, 38-46. [CrossRef]

34. Fereres, A.; Lister, R.M.; Araya, J.E.; Foster, J.E. Development and reproduction of the English grain aphid (Homoptera: Aphididae) on wheat cultivars infected with Barley yellow dwarf virus. Environ. Entomol. 1989, 18, 388-393. [CrossRef]

35. Wyatt, I.J.; White, P.F. Simple estimation of intrinsic increase rates for aphids and tetranychid mites. J. Appl. Ecol. 1977, 14,757-766. [CrossRef]

36. Birch, L.C. The Intrinsic Rate of Natural Increase of an Insect Population. J. Anim. Ecol. 1948, 17, $15-26$. [CrossRef]

37. Dixon, A.F.G. Parthenogenetic reproduction and the rate of increase in aphids. In Aphids: Their Biology, Natural Enemies and Control; Minks, A.K., Harrewinjn, P., Eds.; Elsevier: Amsterdam, The Netherlands, 1987; pp. 269-287.

38. Tjallingii, W.F. Electrical recording of stylet penetration activities. In Aphids, Their Biology, Natural Enemies and Control; Minks, A.K., Harrewijn, P., Eds.; Elsevier Science Publishers: Amsterdam, The Netherlands, 1988; pp. 95-108.

39. Moreno-Delafuente, A.; Garzo, E.; Moreno, A.; Fereres, A. A Plant Virus Manipulates the Behavior of Its Whitefly Vector to Enhance Its Transmission Efficiency and Spread. PLoS ONE 2013, 8, e61543. [CrossRef] [PubMed]

40. Sarria, E.; Cid, M.; Garzo, E.; Fereres, A. Workbook for automatic parameter calculation of EPG data. Comput. Electron. Agric. 2009, 67, 35-42. [CrossRef]

41. Backus, E.A.; Cline, A.R.; Ellerseick, M.R.; Serrano, M.S. Ligus hesperus (Hemiptera: Miridae) Feeding on Cotton: New Methods and Parameters for Analysis of Nonsequential Electrical Penetration Graph Data. Ann. Entomol. Soc. Am. 2007, 100, 296-310. [CrossRef]

42. Wanumen, A.C.; Sánchez-Ramos, I.; Viñuela, E.; Medina, P.; Adán, Á. Impact of feeding on contaminated prey on the life parameters of Nesidiocoris tenuis (Hemiptera: Miridae) adults. J. Insect Sci. 2016, 16, 1-7. [CrossRef]

43. Goel, M.; Khanna, P.; Kishore, J. Understanding survival analysis: Kaplan-Meier estimate. Int. J. Ayurveda Res. 2010, 1, 274. [CrossRef]

44. Prado, E.; Tjallingii, W.F. Aphid activities during sieve element punctures. Entomol. Exp. Appl. 1994, 72, 157-165. [CrossRef]

45. Foster, S.E.; Devine, G.; Devonshire, A. Insecticide Resistance. In Aphids as Crop Pests; Van Emden, H.F., Harrington, R., Eds.; CAB International: Oxfordshire, UK, 2017; pp. 426-447. 
46. Choh, Y.; Ozawa, R.; Takabayashi, J. Effects of exogenous Jasmonic acid and benzo $(1,2,3)$ thiadiazole-7-carbothioic acid S-methyl ester (BTH), a functional analogue of salicylic acid, on the egg production of a herbivorous mite Tetranychus urticae (Acari: Tetranychidae). Appl. Entomol. Zool. 2004, 39, 311-314. [CrossRef]

47. Sarwar, N.; Zahid, C.; Haq, I.; Jamil, F.F. Induction of systemic resistance in chickpea against Fusarium wilt by seed treatment with salicylic acid and Bion. Pak. J. Bot. 2005, 37, 989-995.

48. Inbar, M.; Doostdar, H.; Gerling, D.; Mayer, R.T. Induction of systemic acquired resistance in cotton by BTH has a negligible effect on phytophagous insects. Entomol. Exp. Appl. 2001, 99, 65-70. [CrossRef]

49. Hodge, S.; Ward, J.L.; Galster, A.M.; Beale, M.H.; Powell, G. The effects of a plant defence priming compound, $\beta$-aminobutyric acid, on multitrophic interactions with an insect herbivore and a hymenopterous parasitoid. BioControl 2011, 56, 699-711. [CrossRef]

50. Rodríguez-López, M.J.; Garzo, E.; Bonani, J.P.; Fereres, A.; Fernández-Muñoz, R.; Moriones, E. Whitefly resistance traits derived from the wild tomato Solanum pimpinellifolium affect the preference and feeding behavior of Bemisia tabaci and reduce the spread of Tomato yellow leaf curl virus. Phytopathology 2011, 101, 1191-1201. [CrossRef] [PubMed]

51. Garzo, E.; Moreno, A.; Hernando, S.; Mariño, V.; Torne, M.; Santamaria, E.; Díaz, I.; Fereres, A. Electrical penetration graph technique as a tool to monitor the early stages of aphid resistance to insecticides. Pest Manag. Sci. 2015, 72, 707-718. [CrossRef] [PubMed]

52. Garzo, E.; Soria, C.; Gomez-Guillamon, M.L.; Fereres, A. Feeding behavior of Aphis gossypii on resistant accessions of different melon genotypes (Cucumis melo). Phytoparasitica 2002, 30, 129-140. [CrossRef]

53. Powell, G.; Hodge, S. Effects of $\beta$-aminobutyric acid on aphid stylet activities. Induc. Resist. Plants Against Insects Dis. IOBC-WPRS Bull. 2018, 135, 124-126.

54. Vlot, A.C.; Dempsey, D.A.; Klessig, D.F. Salicylic acid, a multifaceted hormone to combat disease. Annu. Rev. Phytopathol. 2009, 47, 177-206. [CrossRef] [PubMed]

55. Cooper, W.R.; Goggin, F.L. Effects of jasmonate-induced defenses in tomato on the potato aphid, Macrosiphum euphorbiae. Entomol. Exp. Appl. 2005, 115, 107-115. [CrossRef]

56. Strapasson, P.; Pinto-Zevallos, D.M.; Paudel, S.; Rajotte, E.G.; Felton, G.W.; Zarbin, P.H.G. Enhancing Plant Resistance at the Seed Stage: Low Concentrations of Methyl Jasmonate Reduce the Performance of the Leaf Miner Tuta absoluta but do not Alter the Behavior of its Predator Chrysoperla externa. J. Chem. Ecol. 2014, 40, 1090-1098. [CrossRef]

57. Karatolos, N.; Hatcher, P.E. The effect of acetylsalicylic acid and oxalic acid on Myzus persicae and Aphidius colemani. Entomol. Exp. Appl. 2009, 130, 98-105. [CrossRef]

58. Garzo, E.; Moreno, A.; Plaza, M.; Fereres, A. Feeding Behavior and Virus-transmission Ability of Insect Vectors Exposed to Systemic Insecticides. Plants 2020, 9, 895. [CrossRef]

59. Stevens, M.; Lacomme, C. Transmission of Plant Viruses. In Aphids as Crop Pests; Van Emden, H.F., Harrington, R., Eds.; CAB International: Wallingford, UK, 2017; pp. 323-361, ISBN 978-1-78064-709-8.

Publisher's Note: MDPI stays neutral with regard to jurisdictional claims in published maps and institutional affiliations.

(C) 2020 by the authors. Licensee MDPI, Basel, Switzerland. This article is an open access article distributed under the terms and conditions of the Creative Commons Attribution (CC BY) license (http://creativecommons.org/licenses/by/4.0/). 